PIMENTA, S; MENEZES, D; NEDER, DG; MELO, RA; ARAUJO, ALR; MARANHÃO, EAA. 2016. Adaptability and stability of pepper hybrids under conventional and organic production systems. Horticultura Brasileira 34: 168-174. DOI - http://dx.doi.org/10.1590/S0102-053620160000200004

\title{
Adaptability and stability of pepper hybrids under conventional and organic production systems
}

\author{
Samy Pimenta ${ }^{1}$; Dimas Menezes²; Diogo G Neder³; Roberto A Melo²; Ana LR Araujo²; Elizabeth A A \\ Maranhão ${ }^{4}$ \\ ${ }^{1}$ UENF, Dep ${ }^{\text {to }}$ Agronomia, Campos dos Goytacazes-RJ, Brasil; pimentasamy@gmail.com; ${ }^{2}$ UFRPE, Depo ${ }^{\text {to }}$ Agronomia, Recife-PE, Brasil; \\ dimas@depa.ufrpe.br; robertoagronomo@yahoo.com.br; luisarodrigues21@gmail.com; ${ }^{3} \mathrm{UEPB}$, Dep ${ }^{\text {to }}$ Agroecologia e Agropecuária, \\ Campina Grande-PB, Brasil; dgneder@hotmail.com; ${ }^{4}$ IPA, EE Luiz Jorge da Gama Wanderley, Vitória de Santo Antão-PE, Brasil; beth@ \\ ipa.com.br
}

\begin{abstract}
Pepper is one of the main vegetable crops commercialized in Brazil and it is grown throughout the country. The objective of this study was to estimate genetic parameters and predict the genotypic values involved in agronomic traits of hybrid pepper in two different cropping systems in order to verify adaptability and genotypic stability. The experiment was carried out at the Experimental Station Luiz Jorge da Gama Wanderley from IPA, located in Vitoria de Santo Antão, Pernambuco State, Brazil, from October 2010 to March 2011. Seven hybrids were evaluated in two trials, the first in conventional farming system and the second in organic cultivation system. Randomized blocks were used with seven treatments, four replications and plots consisting of six plants. We evaluated the following fruit variables: total mass (MTF), total number (NTF), average length (CMF), average diameter (DMF), number of locules (NL) and average thickness of the pericarp (EP). Statistical analyzes and estimation of genetic parameters were based on mixed models of type REML/BLUP, using the statistical model and software SELEGEN 151. All traits showed good accuracy. The genotype average heritability $\left(\mathrm{h}^{2}{ }_{\mathrm{mg}}\right)$ was lower than $80 \%$ only for the trait NTF. Some characters had $h^{2}{ }_{m g}$ close to $100 \%$ such as CMF and DMF with $99.1 \%$ and $98.3 \%$, respectively. The hybrids presenting a predicted genotypic effect higher than the average were: Atlantis, Máximos, Solario and Rubia R for NTF, Solario and Atlantis for MFT, Impacto, Máximos, Atlantis, Hebron and Rubia R to CMF, Solario and Enterprise for DMF, Solario, Impacto, Rubia R and Atlantis for NL and Solario and Enterprise for EP. Hybrids presenting the highest performance in the traits evaluated for each system were the same selected based on the joint analysis of the studied systems, showing stability and enabling their indication for organic and conventional cropping systems.
\end{abstract}

Keywords: Capsicum annuum, breeding, genetic parameters, mixed models.

\section{RESUMO}

Adaptabilidade e estabilidade de híbridos de pimentão nos sistemas de cultivo convencional e orgânico

O pimentão é cultivado em todo território nacional, estando entre as principais olerícolas comercializadas no país. O objetivo deste trabalho foi estimar os parâmetros genéticos e predizer os valores genotípicos envolvidos em caracteres agronômicos de híbridos de pimentão, em dois diferentes sistemas de cultivo, a fim de verificar a adaptabilidade e estabilidade genotípica. O experimento foi conduzido na EE Luiz Jorge da Gama Wanderley do IPA, em Vitória de Santo Antão-PE, no período de outubro de 2010 a março de 2011. Foram avaliados híbridos de pimentão em dois ensaios, o primeiro em sistema de cultivo convencional e o segundo em sistema orgânico de cultivo. O delineamento experimental adotado foi em blocos ao acaso, com sete tratamentos sendo representados pelos híbridos, com seis repetições e parcela útil constituída por oito plantas. Avaliaram-se as variáveis relacionadas aos frutos: massa total (MTF); número total $(\mathrm{NTF})$; comprimento médio $(\mathrm{CMF})$; diâmetro médio (DMF); número de lóculos (NL) e espessura média do pericarpo (EP). As análises estatísticas e a estimação dos parâmetros genéticos foram baseadas em modelos mistos do tipo REML/BLUP, empregando o software SELEGEN e o modelo estatístico 151. Todos os caracteres obtiveram boa acurácia. A herdabilidade da média de genótipo $\left(\mathrm{h}_{\mathrm{mg}}{ }_{\mathrm{g}}\right)$ foi abaixo de $80 \%$ apenas para o caráter NTF; em alguns caracteres verificou-se $\mathrm{h}^{2}{ }_{\text {mg }}$ próximos de $100 \%$ como CMF e DMF com $99,1 \% \mathrm{e}$ $98,3 \%$, respectivamente. Os híbridos que obtiveram efeito genotípico predito acima da média foram: para NTF Atlantis, Máximos, Solario e Rubia R; para MFT Solario e Atlantis; para CMF Impacto, Máximos, Atlantis, Hebron e Rubia R; para DMF Solario e Enterprise; para NL Solario, Impacto, Rubia R e Atlantis; para EP os híbridos Solario e Enterprise. Os híbridos de maior desempenho nos caracteres avaliados para cada sistema foram os mesmos selecionados com base na análise conjunta dos sistemas, evidenciando estabilidade e possibilitando a indicação destes para ambos os sistemas de cultivo.

Palavras-chave: Capsicum annuum, melhoramento vegetal, parâmetros genéticos, modelos mistos.

(Recebido para publicação em 11 de setembro de 2014; aceito em 16 de outubro de 2015) (Received on September 11, 2014; accepted on October 16, 2015)

$\mathrm{S}$ weet pepper growing demands relatively mild or high temperatures, between 20 and $30^{\circ} \mathrm{C}$. Temperature lower than $15^{\circ} \mathrm{C}$ is considered a limiting factor for the crop (Pádua et al., 1984). According to a socioeconomic survey on the vegetables production chain in Brazil, carried out by Associação Brasileira do Comércio de Sementes 
e Mudas (ABCSEM), sweet pepper production value exceeds $\mathrm{R} \$ 360$ million and it is among the 10 largest vegetable production value paid to producers in the years 2010 and 2011 (ABCSEM, 2011), highlighting the importance of this vegetable in the Brazilian market.

Genotype $\mathrm{x}$ environment interaction (IGE) is defined by Cruz \& Carneiro (2003) as a consequence of a distinct behavior of genotypes under different environmental conditions. IGE is a major concern for plant breeders, since genotypes may not keep the same agronomic performance when grown in different environments (Kang \& Magari, 1996). On the other hand, genotypic and environmental interactions can offer opportunities, mainly for selection and approval of genotypes with positive interaction in a determined location and its current environmental conditions, exploration of specific adaptation or genotypes with low yield frequency, besides of exploration of production stability (Ceccarelli, 1996).

Some traits do not show difference in phenotypic expression when submitted to environmental changes and to IGE effects. However, traits of economic greatest interest generally are quantitative and, nevertheless, small environmental changes can cause significant phenotypic variations. Several studies on IGE were carried out about cereal, fruits, forest and vegetable species (Marjanović-Jeromela et al., 2011; Srinivasa et al., 2011). Studies carried out by Hoddes et al. (1995) and Stoffella et al. (1995) are highlighted among studies related to IGE for sweet pepper. However, even considering world literature, few studies can be found and more studies would contribute towards most appropriate decisions in relation to the use of cultivars in specific environments or managements.

Considering breeding programs, Bernardo (2002) proposed three positions to be taken before the existence of IGE: ignore it, reduce it or exploit it. Taking into account only the latter situation, breeding can be directed to the maximum exploitation of IGE, allowing obtaining and exploiting genetic variance components $(\mathrm{Vg})$ in selection. The aim is to identify cultivars with better performance in specific environmental conditions. Yet, according to this author, the estimate of the component $(\mathrm{Vg})$ is carried out using analysis of joint variance of environments. However, this procedure does not make it possible to quantify the magnitude of IGE associated with each genotype.

In genetic evaluation and selection, IGE leads to the necessity of generating predictors of genetic and genotypic values for each individual in each environment. This way, each individual has a breeding value or predicted genotypic for each environment in which it is used (Resende, 2002). Genotypic values should be the favorite by breeders, since they are the true ones to be predicted (Borges et al., 2010).

In context of mixed models, selection considering productivity, stability, and adaptability, simultaneously, can be carried out using MHPRVG methodology (Harmonic Mean of the Relative Performance of the Genetic Values) predicted (Resende, 2007). This methodology is similar to Linn \& Binns (1988) method, in genotypic context and not in phenotypic context, though. MHPRVG*MG amount is related to MHPRVG multiplied by the overall average of all locations. It provides average genotypic value penalized by instability and capitalized by the adaptability (Carbonell et al., 2007).

Methodology of mixed models has been used for selection in several perennial cultures like coconut palm (Farias Neto et al., 2009), physic nut

Table 1. Variance components, REML Individual, for fruit traits: total number (NTF), total mass (MTF), average length (CMF), average diameter (DMF), number of locules (NL) and pericarp thickness (EP) \{componentes de variância, REML Individual, para os caracteres relacionados aos frutos: número total (NTF), massa total (MTF), comprimento médio (CMF), diâmetro médio (DMF), número de lóculos (NL) e espessura do pericarpo (EP)\}. Vitória de Santo Antão, IPA, 2011.

\begin{tabular}{lrrrrcc}
\hline \multirow{2}{*}{ Parameters } & \multicolumn{7}{c}{ Traits } \\
\cline { 2 - 7 } & NTF & \multicolumn{1}{c}{ MTF } & CMF & DMF & NL & EP \\
\hline $\mathrm{V}_{\mathrm{g}}$ & 0.039 & 734.221 & 1.976 & 0.300 & 0.016 & 0.001 \\
$\mathrm{~V}_{\mathrm{e}}$ & 1.012 & 13502.872 & 0.444 & 0.252 & 0.083 & 0.002 \\
$\mathrm{~V}_{\mathrm{f}}$ & 1.057 & 14279.699 & 2.319 & 0.557 & 0.101 & 0.003 \\
$\mathrm{~h}_{\mathrm{g}}^{2}$ & 0.037 & 0.051 & 0.797 & 0.539 & 0.161 & 0.433 \\
$\mathrm{r}$ & 0.041 & 0.054 & 0.808 & 0.547 & 0.178 & 0.470 \\
$\mathrm{c}^{2}{ }_{\text {perm }}$ & 0.003 & 0.001 & 0.003 & 0.001 & 0.004 & 0.002 \\
$\mathrm{c}^{2}{ }_{\text {int }}$ & 0.0006 & 0.001 & 0.007 & 0.006 & 0.012 & 0.034 \\
$\mathrm{~h}^{2}{ }_{\mathrm{mg}}$ & 0.750 & 0.808 & 0.991 & 0.983 & 0.905 & 0.947 \\
$\mathrm{~A}_{\text {cgen }}$ & 0.866 & 0.899 & 0.995 & 0.991 & 0.951 & 0.973 \\
$\mathrm{r}_{\text {gloc }}$ & 0.981 & 0.977 & 0.990 & 0.987 & 0.927 & 0.927 \\
$\mathrm{CV}_{\text {gi\% }}$ & 5.499 & 7.621 & 14.489 & 8.187 & 4.035 & 8.864 \\
$\mathrm{CV}_{\mathrm{e}^{\circ} \%}$ & 11.527 & 13.419 & 3.045 & 3.093 & 3.776 & 4.065 \\
General mean & 3.607 & 355.523 & 9.385 & 6.695 & 3.177 & 0.466 \\
\hline${ }_{\mathrm{g}} \mathrm{gen}$ & & &
\end{tabular}

$\mathrm{V}_{\mathrm{g}}$ : genotypic variance (variância genotípica); $\mathrm{V}_{\mathrm{e}}$ : residual variance (variância residual); $\mathrm{V}_{\mathrm{f}}$ : phenotypic individual variance (variância fenotípica individual); $\mathrm{h}_{\mathrm{g}}^{2}$ : broad sense heritability (herdabilidade de parcelas individuais no sentido amplo); r: repeatability of individual plots (repetibilidade de parcelas individuais); $\mathrm{c}^{2}{ }_{\text {perm }}=\mathrm{c}^{2}$ : coefficient of determination of permanent environmental effects (coeficiente de determinação dos efeitos de ambiente permanente); $\mathrm{c}^{2}{ }_{\text {int }}=\mathrm{c}^{2}{ }_{1}$ : coefficient of determination of the effects of genotype $\mathrm{x}$ location interaction (coeficiente de determinação dos efeitos da interação genótipos x locais); $\mathrm{h}^{2}{ }_{\mathrm{mg}}$ : heritability of genotype average (herdabilidade da média de genótipo); $\mathrm{A}_{\text {cgen }}$ : accuracy of selection of genotypes (acurácia da seleção de genótipos); rgloc: genetic correlation between performance in several environments (correlação genotípica entre o desempenho nos vários ambiente); $\mathrm{CV}_{\mathrm{gi} \%}$ : coefficient of genotypic variation (coeficiente de variação genotípica); $\mathrm{CV}_{\mathrm{e} \%}$ : coefficient of residual variation (coeficiente de variação residual). 
(Jatropha curcas) (Juhász et al., 2010), açaí palm (Farias Neto et al., 2011), besides the approach of these models in horticultural crops such as sweet potato (Borges et al., 2010); but on a general analysis, it is still little used in vegetable species.

The aim of this work was to estimate genetic parameters and predict genotypic values involved in agronomic traits of commercial hybrids of sweet pepper, under two different growing systems, in order to verify genotype adaptability and stability.

\section{MATERIAL AND METHODS}

The tests were carried out from October 2010 to March 2011, at Estação Experimental Luiz Jorge da Gama Wanderley from IPA, located at Mesoregion of Forest in the state of Pernambuco, in Vitória de Santo Antão, Pernambuco State, Brazil (8 $8^{\circ} 00^{\prime} \mathrm{S}$, $35^{\circ} 22^{\prime} 00^{\prime} \mathrm{W}, 171 \mathrm{~m}$ elevation). In this mesoregion, the climate is As' type, according to Köppen-Geiger classification, with high temperatures, longer dry season, average annual rainfall between 1,008 and $1,395 \mathrm{~mm}$.

In each test, sweet pepper hybrids were arranged in experimental design in randomized blocks with six replications and useful plot consisted of eight plants, totaling 48 plants evaluated per hybrid. Two plants were used, one plant in the beginning and the other one at the end of each plot as border lines.

We evaluated the hybrids Atlantis (Topsed), Enterprise (Seminis), Hebron (Clause), Impacto (Seminis), Máximos (Clause), Rubia R (Sakata) and Solario (Clause). Seeds were sown in trays with 128 cells containing powdered coconut and Plantmax ${ }^{\circledR}$ commercial substrate (1:1) and kept in a greenhouse. After fourteen days, thinning was carried out. When seedlings reached 10 to 15 $\mathrm{cm}$ height, with 4 to 6 definitive leaves, they were transplanted into the field at 25 days after sowing.

Tillage, for conventional and organic growing, consisted of plowing at 30 $\mathrm{cm}$, followed by a leveling harrowing operation. Furrows with $25 \mathrm{~cm}$ width,
$20 \mathrm{~cm}$ depth and slope of $0.2 \%$ to $0.5 \%$ were carried out. Spacing was of $1.0 \times 0.6$ $\mathrm{m}$. The sprinkler irrigation system was used with two irrigation shifts and the amount of water available ranged according to vegetative development correlated with weather conditions of the day. Cultural practices were used according to the recommended for the crop, in conventional and organic growing system (Souza, 2006).

For the conventional system, fertilization was carried out according to the soil analysis. Foundation fertilization applied consisted of $6.6 \mathrm{~g}$ of urea, 150 $\mathrm{g}$ of superphosphate, 21.0 of potassium chloride, 2 L of tanned cattle manure per meter. Top dressing consisted of 10

Table 2. Hybrid ranking selected based on all systems and for all the traits related to fruit: total number (NTF), total mass (MTF), average length (CMF), average diameter (DMF), number of locules (NL) and pericarp thickness (EP) \{ordem dos híbridos selecionados considerando todos os sistemas e para os caracteres relacionados aos frutos: número total (NTF), massa total (MTF), comprimento médio (CMF), diâmetro médio (DMF), número de lóculos (NL) e espessura do pericarpo (EP)\}. Vitória de Santo Antão, IPA, 2011.

\begin{tabular}{|c|c|c|c|c|c|c|c|c|}
\hline Trait & Rank & $\mathbf{1}^{\mathrm{o}}$ & $2^{\circ}$ & $3^{0}$ & $4^{0}$ & $5^{\circ}$ & $6^{0}$ & $7^{0}$ \\
\hline \multirow{5}{*}{ NTF } & Hybrids & 1 & 5 & 7 & 6 & 2 & 4 & 3 \\
\hline & G & 0.27 & 0.07 & 0.06 & 0.02 & -0.07 & -0.09 & -0.27 \\
\hline & $\mathrm{u}+\mathrm{g}$ & 3.88 & 3.68 & 3.67 & 3.63 & 3.53 & 3.50 & 3.33 \\
\hline & New mean & 3.88 & 3.78 & 3.74 & 3.71 & 3.68 & 3.65 & 3.60 \\
\hline & $\mathrm{u}+\mathrm{g}+\mathrm{gem}$ & 3.88 & 3.68 & 3.67 & 3.63 & 3.53 & 3.50 & 3.33 \\
\hline \multirow{5}{*}{ MTF } & Hybrids & 7 & 1 & 2 & 5 & 4 & 3 & 6 \\
\hline & g & 4578 & 19.04 & -3.33 & -5.41 & -17.85 & -18.12 & -20.10 \\
\hline & $\mathrm{u}+\mathrm{g}$ & 401.30 & 374.5 & 352.19 & 350.10 & 337.67 & 337.39 & 335.42 \\
\hline & New mean & 401.30 & 387.93 & 376.02 & 369.54 & 363.16 & 358.87 & 355.52 \\
\hline & $\mathrm{u}+\mathrm{g}+\mathrm{gem}$ & 401.83 & 374.78 & 352.15 & 350.04 & 337.46 & 337.19 & 335.19 \\
\hline \multirow{5}{*}{$\mathrm{CMF}$} & Hybrids & 4 & 5 & 1 & 3 & 6 & 7 & 2 \\
\hline & $\mathrm{g}$ & 1.15 & 0.96 & 0.95 & 0.52 & 0.25 & -1.76 & -2.10 \\
\hline & $\mathrm{u}+\mathrm{g}$ & 10.54 & 10.34 & 10.33 & 9.90 & 9.64 & 7.62 & 7.34 \\
\hline & New mean & 10.54 & 10.44 & 10.41 & 10.28 & 10.15 & 9.73 & 9.45 \\
\hline & $\mathrm{u}+\mathrm{g}+\mathrm{gem}$ & 10.55 & 10.35 & 10.34 & 9.90 & 9.64 & 7.61 & 7.30 \\
\hline \multirow{5}{*}{ DMF } & Hybrids & 7 & 2 & 3 & 1 & 6 & 5 & 4 \\
\hline & G & 0.75 & 0.73 & -0.03 & -0.10 & -0.29 & -0.43 & -0.62 \\
\hline & $\mathrm{u}+\mathrm{g}$ & 7.44 & 7.42 & 6.66 & 6.59 & 6.40 & 6.25 & 6.07 \\
\hline & New mean & 7.44 & 7.43 & 7.17 & 7.03 & 6.90 & 6.79 & 6.69 \\
\hline & $\mathrm{u}+\mathrm{g}+\mathrm{gem}$ & 7.45 & 7.43 & 6.66 & 6.59 & 6.40 & 6.25 & 6.07 \\
\hline \multirow{5}{*}{ NL } & Hybrids & 7 & 4 & 6 & 1 & 3 & 2 & 5 \\
\hline & $\mathrm{g}$ & 0.12 & 0.11 & 0.10 & 0.01 & -0.05 & -0.15 & -0.15 \\
\hline & $\mathrm{u}+\mathrm{g}$ & 3.30 & 3.29 & 3.27 & 3.19 & 3.12 & 3.02 & 3.02 \\
\hline & New mean & 3.30 & 3.29 & 3.29 & 3.26 & 3.23 & 3.20 & 3.17 \\
\hline & $\mathrm{u}+\mathrm{g}+\mathrm{gem}$ & 3.30 & 3.30 & 3.28 & 3.19 & 3.12 & 3.02 & 3.01 \\
\hline \multirow{5}{*}{ EP } & Hybrids & 7 & 2 & 5 & 1 & 3 & 4 & 6 \\
\hline & g & 0.07 & 0.03 & -0.01 & -0.01 & -0.02 & -0.02 & -0.02 \\
\hline & $\mathrm{u}+\mathrm{g}$ & 0.54 & 050 & 0.44 & 0.44 & 0.44 & 0.44 & 0.43 \\
\hline & New mean & 0.54 & 0.52 & 0.49 & 0.48 & 0.47 & 0.47 & 0.46 \\
\hline & $\mathrm{u}+\mathrm{g}+\mathrm{gem}$ & 0.54 & 0.50 & 0.44 & 0.44 & 0.44 & 0.43 & 0.43 \\
\hline
\end{tabular}

$\mathrm{g}=$ predicted genotypic effect (efeito genotípico predito) $\mathrm{u}+\mathrm{g}=$ genotypic mean or genotypic values (média genotípica ou valores genotípicos); $\mathrm{u}+\mathrm{g}+\mathrm{gem}=$ genotypic value (valor genotípico); Hybrids (híbridos) $1=$ Atlantis, $2=$ Enterprise, $3=$ Hebron, $4=$ Impacto, $5=$ Máximos, $6=$ Rubia R, $7=$ Solario. 
Table 3. Hybrid ranking selected considering each cropping system and fruit traits: total number (NTF), total mass (MTF), average length (CMF), average diameter (DMF), number of locules (NL) and pericarp thickness (EP) \{ordem dos híbridos selecionados considerando cada sistema de cultivo e para os caracteres relacionados aos frutos: número total (NTF), massa total (MTF), comprimento médio (CMF), diâmetro médio (DMF), número de lóculos (NL) e espessura do pericarpo (EP)\}. Vitória de Santo Antão, IPA, 2011.

\begin{tabular}{|c|c|c|c|c|c|c|c|}
\hline \multirow[b]{2}{*}{ Location } & \multirow[b]{2}{*}{ Rank } & \multicolumn{2}{|c|}{ NTF } & \multicolumn{2}{|c|}{ MTF } & \multicolumn{2}{|c|}{ CMF (cm) } \\
\hline & & Hybrids & $\begin{array}{l}\text { New } \\
\text { mean }\end{array}$ & Hybrids & $\begin{array}{l}\text { New } \\
\text { mean }\end{array}$ & Hybrids & $\begin{array}{l}\text { New } \\
\text { mean }\end{array}$ \\
\hline \multirow{7}{*}{1} & $1^{\circ}$ & Atlantis & 4.01 & Solario & 392.56 & Impacto & 10.36 \\
\hline & $2^{o}$ & Máximos & 3.90 & Atlantis & 378.56 & Máximos & 10.28 \\
\hline & $3^{\circ}$ & Solario & 3.87 & Enterprise & 366.28 & Atlantis & 10.20 \\
\hline & $4^{\circ}$ & Rubia R & 3.84 & Máximos & 359.58 & Hebron & 10.04 \\
\hline & $5^{\circ}$ & Enterprise & 3.80 & Impacto & 353.29 & Rubia R & 9.91 \\
\hline & $6^{\circ}$ & Impacto & 3.77 & Hebron & 348.88 & Solario & 9.50 \\
\hline & $7^{\circ}$ & Hebron & 3.73 & Rubia R & 345.41 & Enterprise & 9.15 \\
\hline \multirow{8}{*}{2} & $1^{\circ}$ & Atlantis & 3.76 & Solario & 411.10 & Impacto & 10.73 \\
\hline & $2^{o}$ & Máximos & 3.66 & Atlantis & 398.05 & Atlantis & 10.67 \\
\hline & $3^{\circ}$ & Solario & 3.62 & Enterprise & 386.22 & Máximos & 10.62 \\
\hline & $4^{\circ}$ & Rubia R & 3.59 & Máximos & 379.82 & Hebron & 10.53 \\
\hline & $5^{\circ}$ & Enterprise & 3.55 & Hebron & 373.36 & Rubia R & 10.40 \\
\hline & $6^{\circ}$ & Impacto & 3.52 & Impacto & 368.94 & Solario & 9.96 \\
\hline & $7^{\circ}$ & Hebron & 3.48 & Rubia R & 365.62 & Enterprise & 9.61 \\
\hline & & \multicolumn{2}{|c|}{ DMF (mm) } & \multicolumn{2}{|c|}{ NL } & \multicolumn{2}{|c|}{$\mathrm{EP}(\mathrm{mm})$} \\
\hline \multirow{7}{*}{1} & $1^{\circ}$ & Solario & 7.40 & Solario & 3.335 & Solario & 0.53 \\
\hline & $2^{\circ}$ & Enterprise & 7.36 & Impacto & 3.330 & Enterprise & 0.51 \\
\hline & $3^{\circ}$ & Hebron & 7.11 & Rubia R & 3.32 & Atlantis & 0.48 \\
\hline & $4^{\circ}$ & Atlantis & 6.97 & Atlantis & 3.29 & Máximos & 0.47 \\
\hline & $5^{\circ}$ & Rubia R & 6.85 & Hebron & 3.27 & Hebron & 0.47 \\
\hline & $6^{\circ}$ & Máximos & 6.74 & Máximos & 3.22 & Rubia R & 0.46 \\
\hline & $7^{\circ}$ & Impacto & 6.64 & Enterprise & 3.13 & Impacto & 0.46 \\
\hline \multirow{7}{*}{2} & $1^{\circ}$ & Enterprise & 7.53 & Impacto & 3.278 & Solario & 0.55 \\
\hline & $2^{\circ}$ & Solario & 7.52 & Solario & 3.277 & Enterprise & 0.53 \\
\hline & $3^{\circ}$ & Hebron & 7.25 & Rubia R & 3.26 & Máximos & 0.51 \\
\hline & $4^{\circ}$ & Atlantis & 7.09 & Atlantis & 3.24 & Atlantis & 0.49 \\
\hline & $5^{\circ}$ & Rubia R & 6.96 & Hebron & 3.21 & Hebron & 0.48 \\
\hline & $6^{\circ}$ & Máximos & 6.84 & Enterprise & 3.18 & Impacto & 0.47 \\
\hline & $7^{\circ}$ & Impacto & 6.74 & Máximos & 3.15 & Rubia R & 0.47 \\
\hline
\end{tabular}

Location 1 conventional cropping system (sistema de cultivo convencional) and location 2 organic cropping system (sistema de cultivo orgânico).

$\mathrm{g}$ of urea per plant from the beginning of fruit production, with intervals of 15 days. In organic cultivation and based on soil analysis, the foundation fertilization was formulated, applying per meter: $60 \mathrm{~g}$ of castor bean cake, 142 $\mathrm{g}$ of rock phosphate, $162 \mathrm{~g}$ of potassium sulphate and $2 \mathrm{~L}$ of tanned manure. For top dressing, tanned manure and castor bean cake was applied, in intervals of 15 days from the transplanting up to the considering the totals, NTF and MTF, and averages per plots, $\mathrm{CMF}, \mathrm{DMF}, \mathrm{NL}$ and EP, generating one observation per plot. Statistical analyses and estimate of genetic parameters were based on mixed models methodology REML/BLUP, using software SELEGEN, Genetic Statistical Software (Resende, 2007).

Statistics model used was 151 SELEGEN-REML/BLUP, to verify hybrid effect in growing systems, this model was obtained through: $\mathrm{y}=\mathrm{Xm}$ $+\mathrm{Zg}+\mathrm{Tp}+\mathrm{Wi}+\mathrm{e}$, in which $\mathrm{y}$ is the data vector, $m$ is the effect vector of combinations measurement-repetitionlocal, assumed to be fixed, added to the overall average, $g$ is the vector of genotypic effects, assumed to be random, $\mathrm{p}$ is the vector of permanent environmental effects (randomized plots, random), $i$ is the vector of the effects of genotype $\mathrm{x}$ location interaction, assumed to be random, and "e" is the vector of errors or residues, (random). The capital letters represent incidence matrices for these effects. Vector $m$ contemplates all measurements in all replications in several locals and simultaneously adjusting for all of these effects and interactions. It is essential that the measurements are coded with different numbers in different locations and repetitions (Resende, 2007).

\section{RESULTS AND DISCUSSION}

Considering experimental precision, the authors verified values for coefficient of experimental variation $\left(\mathrm{CV}_{\mathrm{e}}\right)$ and accuracy (Table 1). The study showed $\mathrm{CV}_{\mathrm{e}}$ between moderate to low, confirming good experimental precision (Gomes, 2000; Silva et al., 2011). Resende \& Duarte (2007), consider $\mathrm{CV}_{\mathrm{e}}$ values an inappropriate parameter to evaluate the quality of the experiment, since they do not inform the selective accuracy of evaluation and, consequently, it does not consider the level of genotypic variation and number of replications. The same authors state that accuracy is the best parameter to measure experimental precision. Assuming, for example, the fact that in selection processes in plant breeding, accurate values higher than $70 \%$ should be sought. The values of this 
Table 4. Stability and adaptability of genetic values (MHPRVG) for fruit traits: total number (NTF), total mass (MTF), average length (CMF), average diameter (DMF), number of locules (NL) and pericarp thickness (EP) \{estabilidade e adaptabilidade de valores genéticos (MHPRVG) para os caracteres relacionados aos frutos: número total (NTF), massa total (MTF), comprimento médio (CMF), diâmetro médio (DMF), número de lóculos (NL) e espessura do pericarpo (EP)\}. Vitória de Santo Antão, IPA, 2011.

\begin{tabular}{lcccccccc}
\hline Trait & Rank & $\mathbf{1}^{\mathbf{0}}$ & $\mathbf{2}^{\mathbf{0}}$ & $\mathbf{3}^{\mathbf{0}}$ & $\mathbf{4}^{\mathbf{0}}$ & $\mathbf{5}^{\mathbf{0}}$ & $\mathbf{6}^{\mathbf{0}}$ & $\mathbf{7}^{\mathbf{0}}$ \\
\hline \multirow{3}{*}{ NFT } & Hybrids & 1 & 5 & 7 & 6 & 2 & 4 & 3 \\
& MHPRVG & 1.08 & 1.02 & 1.01 & 1.00 & 0.98 & 0.97 & 0.92 \\
& MHPRVG*MG & 3.88 & 3.68 & 3.67 & 3.63 & 3.53 & 3.50 & 3.33 \\
\hline \multirow{3}{*}{ MTF } & Hybrids & 7 & 1 & 2 & 5 & 4 & 3 & 6 \\
& MHPRVG & 1.13 & 1.05 & 0.99 & 0.98 & 0.96 & 0.95 & 0.94 \\
& MHPRVG*MG & 401.8 & 374.7 & 352.1 & 350.0 & 337.4 & 337.1 & 335.1 \\
\hline \multirow{3}{*}{ CMF } & Hybrids & 4 & 5 & 1 & 3 & 6 & 7 & 2 \\
& MHPRVG & 1.12 & 1.11 & 1.10 & 1.05 & 1.02 & 0.81 & 0.77 \\
& MHPRVG*MG & 10.55 & 10.35 & 10.34 & 9.90 & 9.64 & 7.61 & 7.28 \\
\hline \multirow{3}{*}{ DMF } & Hybrids & 7 & 2 & 3 & 1 & 6 & 5 & 4 \\
& MHPRVG & 1.11 & 1.10 & 0.99 & 0.98 & 0.95 & 0.93 & 0.90 \\
\hline \multirow{3}{*}{ NL } & MHPRVG*MG & 7.45 & 7.42 & 6.66 & 6.59 & 6.40 & 6.25 & 6.07 \\
& Hybrids & 7 & 4 & 6 & 1 & 3 & 2 & 5 \\
& MHPRVG & 1.05 & 1.04 & 1.03 & 1.00 & 0.98 & 0.95 & 0.94 \\
EP & MHPRVG*MG & 3.31 & 3.30 & 3.28 & 3.19 & 3.12 & 3.02 & 3.01 \\
\hline & Hybrids & 7 & 2 & 5 & 1 & 3 & 4 & 6 \\
& MHPRVG & 1.16 & 1.07 & 0.96 & 0.95 & 0.95 & 0.94 & 0.93 \\
& MHPRVG*MG & 0.54 & 0.50 & 0.44 & 0.44 & 0.44 & 0.43 & 0.43 \\
\hline
\end{tabular}

MHPRVG*MG refers to MHPRVG multiplied by general average of all systems (MHPRVG*MG refere-se à MHPRVG multiplicada pela média geral de todos os sistemas); Hybrids (híbridos) 1=Atlantis; 2=Enterprise; 3=Hebron; 4=Impacto; 5= Máximos; 6=Rubia R; 7=Solario.

experiment are considered good, since the lowest value of accuracy was $86.6 \%$ for NTF. Thus, all the traits obtained good accuracy.

Estimates of heritability coefficient at the individual level $\left(\mathrm{h}^{2}{ }_{\mathrm{g}}\right)$ in the broad sense, were from low to high magnitude, for the traits evaluated (Table 1), ranging from $3.7 \%$ to $79.7 \%$. Usually, $\mathrm{h}_{\mathrm{g}}^{2}$ of low magnitude are common for quantitative traits and, generally, lead to moderate to high magnitudes of heritability at medium level of breeding lines (Resende, 2002). In this sense, heritability of genotype average $\left(\mathrm{h}^{2}{ }_{\mathrm{mg}}\right)$ was below $80 \%$ only for NFT, some traits presented $\mathrm{h}^{2}{ }_{\mathrm{mg}}$ close to 100\% like CMF and DMF, 99.1\% and 98.3\%, respectively. Rêgo et al. (2011) evaluated heritability in 14 morphologic traits in Capsicum baccatum and for all of them these were higher than $80 \%$ and results were also similar to the ones available in literature for species of genus Capsicum (Rêgo et al., 2009).

Determination coefficient of effects of genotype $\mathrm{x}$ location interaction $\left(\mathrm{c}^{2}{ }_{\text {int }}\right)$ were of low magnitude under two growing systems (Table 1), showing that the used experimental design was appropriate, thus environmental heterogeneity was not maintained into the blocks. Genotypic correlation among hybrid performances for the systems shows values of high magnitude, indicating that genotype $\mathrm{x}$ system interaction is low.

The hybrid ranking evaluated considering two systems for traits evaluated, the results are related to genotypic predicted effects $(\mathrm{g})$ and values $(\mathrm{u}+\mathrm{g})$, free from all environmental interaction (Table 2). Quantity ( $\mathrm{u}+\mathrm{g}$ + gem) is related to average genotypic value in several environments and capitalizes an average interaction with all evaluated environments (Resende, 2002). Top-ranked hybrids, consequently, hybrids with predicted genotypic effect above average for NTF were Atlantis, Máximos, Solario and Rubia R; for MTF, Solario and Atlantis and for CMF Impacto, Máximos, Atlantis, Hebron and Rubia R.
Solario has shown higher values for DMF, NL and EP, when comparing to other hybrids (Table 2). Using predicted genotypic values, hybrids Solario and Enterprise were above average for DMF. The same for NL, for hybrids Solario, Impacto, Rubia R and Atlantis. For EP, hybrids Solario and Enterprise also stood out. The latter traits are important for sweet pepper breeding programs. Tavares et al. (1999) suggested, through correlation analysis, the fact that total fruit mass is higher in plants which produce fruits with lower width and greater number of locules. Similarly, Rêgo et al. (2011) obtained positive correlation between width and average fruit mass, and negative between width and average fruit length evaluating these traits in 40 accessions of $C$. baccatum.

Hybrids were ranked considering their performance in each growing system for the analyzed traits (Table 3). For NTF, MTF, and CMF, the best hybrid in one system was the same in the other one, however with different averages. Thus for NTF, the best ranked 
hybrid was Atlantis, for MTF, Solario, and for CMF, Impacto. For these traits, the hybrids obtained average best performance in conventional growing system when compared to organic system.

When the authors used DMF, NL and EP to rank the hybrids, considering only the conventional system, the hybrid Solario obtained the best averages, 7.4 $\mathrm{cm}$ for DMF; 3.35 for NL; and $0.53 \mathrm{~mm}$ for EP. Whereas under organic system, the ranking of hybrids varied for each trait, the hybrid Enterprise presenting $7.53 \mathrm{~cm}$ for DMF, hybrid Impacto for NL and hybrid Solario for EP with 0.55 $\mathrm{cm}$. This latter ranking is similar to the one found in conventional system. Considering the dissimilar ranking of hybrids for DMF in the organic system, a superior performance of hybrid Enterprise was observed, since 'Solario' showed the best performance in conventional system, with superior average in organic system, $7.52 \mathrm{~mm}$. It ranked second place in hybrid ordering, though.

The suitability of these genotypes behaving well in wide amplitude of environmental conditions is a desired requirement for breeding programs. This fact highlights the importance of studying stability. According to Resende (2002), a genotype is considered steady when only small variations in its general performance are observed, when evaluated in several environmental conditions. In relation to adaptability, a genotype is considered more adapted when it shows good response capacity to environmental improving.

The study estimated stability and adaptability of genetic values (MHPRVG), for traits of sweet pepper evaluated in conventional and organic growing systems (Table 4). Comparing the resulting rankings of these selection simulations, among seven hybrids listed in the joint analysis of the systems, the authors observed that hybrid Solario showed average genotype superiority in all traits evaluated, with exception for NTF and CMF, in which, hybrids Atlantis and Impacto, respectively, were better ranked. The study also verified that, although the order of selection is not exactly the same, the best hybrids for these traits coincide with the best selected ones based on the individual analysis of each system, it means, the hybrids with best ranking in each system coincide with the ranking considering the joint analysis of all the systems. This is favorable, as it shows that more productive hybrids are also stable and present high adaptability.

\section{ACKNOWLEDGEMENTS}

To UFRPE (Universidade Federal Rural de Pernambuco) and IPA (Estação Experimental Luiz Jorge da Gama Wanderley) for institutional support. CNPq (The National Council for Scientific and Technological Development) for support to Solanaceae breeding program project. FACEPE (Fundação de Amparo à Ciência e Tecnologia do Estado de Pernambuco) for Master scholarship. PROCAD (National Program of Academic Cooperation). CAPES (Coordination of Improvement of Higher Education Personnel) for expenditure support during stay in UFLA (Universidade Federal de Lavras).

\section{REFERENCES}

ABCSEM - Associação Brasileira do Comércio de Sementes e Mudas. 2011. 29 de fevereiro. Projeto para o levantamento dos dados socioeconômicos da cadeia produtiva de hortaliças no Brasil, 2010/2011. Disponível em http://www.agricultura.gov.br/arqeditor/ file/camaras_setoriais/Hortalicas/Dados_ Economicos/ABCSEM\%202011.pdf.

BERNARDO, R. 2002. Breeding for quantitative traits in plants. Stemma Press: Woodbury Minesota, 369p.

BORGES, V; FERREIRA, PV; SOARES, L; SANTOS, GM; SANTOS, AMM. 2010. Seleção de clones de batata-doce pelo procedimento REML/BLUP. Acta Scientiarum Agronomy 32: 643-649.

CARBONELL, SAM; CHIORATO, AF; RESENDE, MDV; DIAS, LAS; BERALDO, ALA; PERINA, EF. 2007. Estabilidade de cultivares e linhagens de feijoeiro em diferentes ambientes no estado de São Paulo. Bragantia 66: 193-201.

CECCARELLI, S. 1996. Positive interpretation of genotype by environment interaction in relation to sustainability and biodiversity, in Cooper \& Hammer. p. 467-486.

CRUZ, CD; CARNEIRO, PCS. 2003. Modelos biométricos aplicados ao melhoramento genético. Viçosa: UFV. 585p.

FARIAS NETO, JT; LINS, PMP; RESENDE, MDV; MULLER, AA. 2009. Seleção genética em progênies híbridas de coqueiro. Revista Brasileira de Fruticultura 31: 190-196.

FARIAS NETO, JT; RESENDE, MDV; OLIVEIRA, MSP. 2011. Seleção simultânea em progênies de açaizeiro irrigado para produção e peso do fruto. Revista Brasileira de Fruticultura 33: 532-539.

GOMES, FP. 2000. Curso de estatística experimental. 14 ${ }^{\mathrm{a}}$ ed. Piracicaba: Degaspari. $477 \mathrm{p}$.

HODDES, L; SANDERS, DC; PERRY, KB; ESKRIDGE, KM; BATAL, KM; GRANBERRY, DM; MCLAURIN, WJ; DECOTEAU, D; DUFAULT, RJ; GARRETT, JT; NAGATA, R. 1995. Adaptability and reliability of yield for four bell pepper cultivars across three southeastern states. Hostscience 30: 1205-1210.

JUHÁSZ, ACP; MORAIS, DLB; SOARES, BO; PIMENTA, S; RABELLO, HO; RESENDE, MDV. 2010. Parâmetros genéticos e ganhos com a seleção para a população de pinhãomanso (Jatropha curcas). Pesquisa Florestal Brasileira 30: 25-35.

KANG, MS; MAGARI, R. 1996. New developments in selecting for phenotypic stability in crop breeding. In: KANG, MS; GAUCH, HG (eds). Genotype by environment interaction. Boca Raton: CRC Press. p. 1-14.

LIN, CS; BINNS, MR. 1988. A superiority measure of cultivar performance for cultivar $\mathrm{x}$ location data. Canadian Journal of Plant Science 68: 193-198.

MARJANOVIĆ-JEROMELA, A; NAGL, N; GVOZDANOVIĆ-VARGA, J; HRISTOV, N; KONDIĆ-ŠPIKA, A; VASIĆ, M; MARINKOVIĆ, R. 2011. Genotype by environment interaction for seed yield per plant in rapeseed using ammi model. Pesquisa Agropecuária Brasileira 46: 174-181.

PÁDUA, JG; CASALI, VWD; PINTO, CMF. 1984. Efeitos climáticos sobre o pimentão e pimenta. Informe Agropecuário 10: 11-13.

RÊGO, ER; RÊGO, MM; CRUZ, CD; FINGER, FL; CASALI, VWD. 2011. Phenotypic diversity, correlation and importance of variables for fruit quality and yield traits in Brazilian peppers (Capsicum baccatum). Genetic Resources and Crop Evolution 58: 909-918.

RÊGO, ER; RÊGO, MM; FINGER, FL; CRUZ, CD; CASALI, VWD. 2009. A diallel study componentes and fruit quality in chilli pepper (Capsicum baccatum). Euphytica 168: 275287.

RESENDE, MDV. 2002. Genética biométrica e estatística no melhoramento de plantas perenes. Brasília: Embrapa Informação Tecnológica. $975 \mathrm{p}$.

RESENDE, MDV. 2007. SELEGEN-REML/ $B L U P$ : Sistema estatístico e seleção genética computadorizada via modelos lineares mistos. Colombo: Embrapa Florestas. 359p. 
RESENDE, MDV; DUARTE, JB. 2007. Precisão e controle de qualidade em experimentos de avaliação de cultivares. Pesquisa Agropecuária Tropical 37: 182-194.

SILVA, AR; CECON, PR; RÊGO, ER; NASCIMENTO, M. 2011. Avaliação do coeficiente de variação experimental para caracteres de frutos de pimenteiras. Ceres 58: 168-171
SOUZA, JL. 2006. Manual de horticultura orgânica. Viçosa: Aprenda Fácil. 843p.

SRINIVASA, RP; REDDY, PS; RATHORE, A; REDDY, BVS; PANWAR, S. 2011. Application GGE biplot and AMMI model to evaluate sweet sorghum (Sorghum bicolor) hybrids for genotype x environment interaction and seasonal adaptation. Indian Journal of Agricultural Sciences 81: 438-444.
STOFFELLA, PJ; LOCASCIO, SJ; HOWE, TK; OLSON, SM; SHULER, KD; VAVRINA, CS. 1995. Yield and fruit size stability differ among bell pepper cultivars. Journal of the American Society for Horticultural Science 120: 325-328.

TAVARES, M; MELO, AMT; SCIVITTARO, WB. 1999. Efeitos diretos e indiretos e correlações canônicas para caracteres relacionados com a produção de pimentão. Bragantia 58: 41-47. 